\title{
KOMORBIDITAS PADA PENYANDANG CEREBRAL PALSY (CP) DI SEKOLAH LUAR BIASA (SLB)
}

\section{Hazna Nadya Nurfadilla, Uni Gamayani, dan Gita Tiara Dewi Nasution}

Fakultas Kedokteran, Universitas Padjadjaran Bandung, Indonesia E-mail: haznadilla@gmail.com

\begin{abstract}
ABSTRAK. Cerebral palsy merupakan sekelompok gangguan neurologis yang timbul pada masa bayi atau kanak-kanak dan secara permanen mempengaruhi gerakan tubuh dan koordinasi otot. Cerebral palsy merupakan gangguan motorik pada anak yang paling sering terjadi. Sebagian besar anak cerebral palsy memiliki setidaknya satu kelainan penyerta atau komorbiditas. Berbagai komorbiditas yang sering menyertai anak cerebral palsy akan berdampak negatif terhadap kualitas hidup anak tersebut dan juga masyarakat luas. Penelitian ini bertujuan untuk mengetahui gambaran komorbiditas pada penyandang cerebral palsy di sekolah luar biasa. Penelitian dilakukan dari bulan Agustus-September 2018 di Sekolah Luar Biasa Negeri Cileunyi, Sekolah Luar Biasa D Yayasan Pembinaan Anak Cacat Bandung, dan Sekolah Luar Biasa Pusat Pengembangan Potensi Anak Suryakanti dengan metode deskriptif potong lintang. Data yang digunakan adalah data primer berupa hasil anamnesis pada orang tua/wali dan hasil pemeriksaan fisik yang dilakukan oleh dokter spesialis saraf. Dari 43 anak, 22 anak adalah laki-laki dan 21 anak adalah perempuan. Usia paling banyak berada pada rentang usia 13-18 tahun. Tipe cerebral palsy sebagian besar adalah tipe spastik tetraplegia.Tingkat Gross Motor Function Classification System yang paling banyak ditemukan adalah tingkat IV. Sebagian besar (90,70\%) anak cerebral palsy di sekolah luar biasa mengalami retardasi mental. Jumlah komorbiditas lebih dari tiga paling banyak ditemukan pada tipe spastik tetraplegia dan pada tingkat Gross Motor Function Classification System IV.
\end{abstract}

Kata kunci: cerebral palsy; komorbiditas; sekolah luar biasa

\begin{abstract}
Cerebral palsy is a group of neurological disorders that appear during infancy or childhood and permanently affect body movements and muscle coordination. Cerebral palsy is the most common motor disorder in children. Most cerebral palsy children have at least one comorbidity. Various comorbidities that often accompany cerebral palsy children will have a negative impact on the quality of life of the child and the wider community. This study aims to find out the description of comorbidities in children with cerebral palsy at special needs schools. The study was conducted from August to September 2018 at Sekolah Luar Biasa Negeri Cileunyi, Sekolah Luar Biasa D Yayasan Pembinaan Anak Cacat Bandung, and Sekolah Luar Biasa Pusat Pengembangan Potensi Anak Suryakanti with descriptive cross-sectional method. The data used in this study are primary data in the form of anamnesis results on parents / guardians and the results of physical examinations performed by neurologists. Of the 43 children, 22 were boys and 21 were girls. The most age is in the age range of 13-18 years. Most types of cerebral palsy are spastic tetraplegia. The level of Gross Motor Function Classification System that is most commonly found is level IV. Most (90,70\%) of cerebral palsy children in special needs school have mental retardation. The number of comorbidities that are more than three is most commonly found in the spastic tetraplegia type and at the Gross Motor Function Classification System level IV.
\end{abstract}

Key words: cerebral palsy; comorbidities; special needs school

\section{PENDAHULUAN}

Cerebral palsy (CP) merupakan istilah deskriptif klinis untuk serangkaian gangguan perkembangan gerak, postur, dan koordinasi yang disebabkan oleh gangguan otak yang bersifat tidak progresif yang berpengaruh pada masa awal perkembangan otak (McInerny TK, 2016). CP merupakan gangguan motorik pada anak yang paling sering terjadi. (Tessier, 2014). Kerusakan otak yang menyebabkan CP dapat terjadi saat prenatal, perinatal, atau bahkan postnatal (Fidan \& Baysal, 2014).

Selama dua puluh tahun terakhir, kejadian CP relatif stabil, berkisar antara 2 sampai 2,5 kasus per 1.000 kelahiran. Sebuah studi yang dilakukan oleh Autism and Developmental Disability Monitoring (ADDM) Cerebral Palsy Network dan Disease Control and Prevention (CDC) melaporkan bahwa rata-rata prevalensi $\mathrm{CP}$ adalah 3,3 per 1.000 kelahiran (Pakula, 2009). Insidensi CP lebih tinggi pada lakilaki dibandingkan dengan perempuan. Surveillance of Cerebral Palsy in Europe (SCPE) melaporkan perbandingan laki-laki : perempuan yaitu $1,33: 1$ (Kumari, 2012).
Di Indonesia, menurut Riset Kesehatan Dasar yang dilakukan oleh Kementerian Kesehatan Republik Indonesia pada tahun 2010, persentasi anak-anak berusia 24-59 bulan dengan CP adalah 0,09\% (WHO, 2013). National Survey of Children's Health (NSCH) pada tahun 2012-2013 dan National Healtth Interview Survey (NHIS) pada tahun 2011-2013 menentukan prevalensi CP melalui laporan orang tua di kalangan anak-anak berusia 2-17 tahun. Survey ini menemukan prevalensi per 1000 kelahiran hidup yang berkisar dari 2,6 di NSCH sampai 2,9 di NHIS (Stavsky, 2017) . Berdasarkan data dari Profil Kesehatan Provinsi Jawa Barat Tahun 2012, angka kelahiran hidup di Kota Bandung adalah 39.442. Dari data tersebut dapat diperkirakan rata-rata insidensi CP di Kota Bandung adalah 102 sampai 114 kasus pada tahun 2012 (Depkes, 2012).

Walaupun CP merupakan kelainan yang bersifat tidak progresif, namun ekspresi klinisnya dapat berubah seiring dengan berjalannya proses pematangan otak (Stavsky, 2017). Gejala CP dan tingkat keparahannya berbeda, tergantung bagian otak yang mengalami kerusakan, dan bahkan mungkin berubah pada satu individu dari waktu ke waktu (NINDS, 2013). 
Sebagian besar anak CP paling sedikit memiliki satu kelainan penyerta atau komorbiditas (CDC, 2016). Gangguan motorik pada anak CP sering disertai dengan gangguan sensasi, persepsi, kognisi, komunikasi dan perilaku, epilepsi, dan masalah muskuloskeletal sekunder (Das, 2016). Menurut data dari SCPE, komorbiditas yang paling umum ditemukan adalah gangguan berbahasa (71\%), diikuti oleh gangguan intelektual (62\%), epilepsi (39\%), dan gangguan penglihatan (22\%). Gangguan pendengaran merupakan komplikasi paling umum yang memperburuk gangguan berbahasa (Gabis, 2015).

Berbagai komorbiditas yang sering menyertai anak CP berdampak negatif terhadap kualitas hidup anak tersebut juga keluarga dan masyarakat (Gabis, 2015). Tingkat keparahan dan prognosis CP bergantung pada bentuk klinis dan adanya komorbiditas yang terkait (Minciu, 2012). Walaupun tidak ada penanganan khusus untuk kerusakan otak yang menyebabkan disfungsi motorik pada $\mathrm{CP}$, intervensi klinis yang berfokus pada pengurangan komorbiditas $\mathrm{CP}$ bisa berdampak positif pada kualitas hidup para penyandang CP (Tessier, 2014).

Sebagai gangguan motorik yang paling sering terjadi pada anak, data mengenai $\mathrm{CP}$ di Indonesia masih terbatas terutama data mengenai gambaran komorbiditas pada penyandang CP dan lebih spesifik lagi yang berbasis pada anak-anak yang bersekolah di sekolah khusus. Berdasarkan uraian di atas peneliti tertarik untuk meneliti dan mengetahui gambaran komorbiditas pada penyandang CP di sekolah luar biasa (SLB).

\section{METODE}

Penelitian ini dilakukan dari bulan AgustusSeptember 2018 di SLB Negeri Cileunyi, SLB D Yayasan Pembinaan Anak Cacat (YPAC) Bandung, dan SLB Pusat Pengembangan Potensi Anak (PUSPPA) Suryakanti dengan menggunakan metode deskriptif potong lintang. Subjek penelitian adalah seluruh siswa/i SLB yang didiagnosis CP dengan kriteria inklusi yaitu siswa/i penyandang CP di SLB serta orang tua/wali bersedia mengikuti penelitian dengan menandatangani informed consent dan kriteria eksklusi berupa orang tua/wali atau anak yang tidak hadir saat pemeriksaan. Jumlah subjek yang didapatkan dalam penelitian ini sebanyak 43 orang yang diambil menggunakan metode total sampling.

Pengambilan data dilakukan setelah adanya surat persetujuan etik No.45/UN6.KEP/EC/2018 dan surat izin penelitian yang selanjutnya diberikan kepada pihak yayasan dan pihak sekolah. Setelah orang tua/ wali mendapatkan penjelasan mengenai penelitian dan menandatangani informed consent, siswa/i yang terdiagnosis $\mathrm{CP}$ akan melalui pemeriksaan fisik oleh dokter spesialis saraf dan diklasifikasikan berdasarkan tipe CP dan tingkat Gross Motor Function Classification System (GMFCS). Anamnesis mengenai komorbiditas yang ada pada peyandang CP dilakukan kepada orang tua/wali siswa. Data yang digunakan adalah data primer berupa jawaban dari hasil anamnesis yang dilakukan kepada orang tua/wali murid SLB dan hasil pemeriksaan neurologis yang dilakukan oleh dokter spesialis saraf.

Dari sudut pandang klinis, CP diklasifikasikan menurut klasifikasi dari SCPE 2002 menjadi tipe spastik, diskinetik, dan ataksik. Tipe spastik kemudian diklasifikasikan lagi berdasarkan topografinya menjadi spastik hemiplegia, spastik diplegia, dan spastik tetraplegia. Tingkat keparahan gangguan motorik diklasifikasikan menurut GMFCS yang pertama kali dipublikasikan oleh Palisano pada tahun 1997. Klasifikasi ini terdiri dari 5 tingkat : Tingkat I - berjalan tanpa keterbatasan, Tingkat II - berjalan dengan keterbatasan, Tingkat III - berjalan dengan alat bantu, Tingkat IV - mobilitas diri mengalami keterbatasan namun kontrol kepala dan batang tubuh masih baik, anak dapat mengoperasikan kursi roda secara manual, Tingkat V - mobilitas diri sangat terbatas begitupun dengan kontrol kepala dan batang tubuh, anak didorong di kursi roda.

Data yang telah didapatkan kemudian dianalisis secara deskriptif dengan menghitung jumlah presentase setiap komorbiditas dan melihat persebarannya berdasarkan tipe CP dan tingkat GMFCS. Variabel pada penelitian ini adalah usia, jenis kelamin, tipe CP, tingkat GMFCS, banyaknya komorbiditas, gangguan berbahasa, epilepsi, gangguan tidur, gangguan makan, gangguan pendengaran, gangguan penglihatan, retardasi mental, dan gangguan buang air besar (BAB) dan buang air kecil (BAK).

\section{HASIL DAN PEMBAHASAN}

Pada penelitian ini didapat 43 anak penyandang CP di SLB Negeri Cileunyi, SLB D YPAC Bandung, dan SLB PUSPPA Suryakanti yang telah melalui proses anamnesis dan pemeriksaan fisik serta telah disetujui oleh orang tua/wali untuk menjadi subjek penelitian dengan menandatangani informed consent.

Tabel 1. Karakteristik umum

\begin{tabular}{lcc}
\hline \multicolumn{1}{c}{ Variabel } & Jumlah (n) & Persentase (\%) \\
\hline Jenis Kelamin & & \\
Laki-laki & 22 & 51,16 \\
Perempuan & 21 & 48,84 \\
Usia (tahun) & & \\
6-12 & 15 & 34,88 \\
13-18 & 19 & 44,19 \\
$>18$ & 9 & 20,93 \\
\hline
\end{tabular}

Tabel 1 menggambarkan karakteristik umum dari subjek penelitian berdasarkan jenis kelamin dan usia. Jumlah anak laki-laki dan perempuan relatif sama yaitu $22(51,16 \%)$ laki-laki dan 21 (48,84\%) perempuan. Sebagian besar anak CP yang bersekolah di SLB adalah usia 13-18 tahun yaitu $19(44,19 \%)$. 
Tabel 2. Klasifikasi CP

\begin{tabular}{lcc}
\hline \multicolumn{1}{c}{ Variabel } & Jumlah (n) & Persentase (\%) \\
\hline Tipe CP & 32 & 74,42 \\
CP Spastik & 9 & 20,93 \\
Spastik hemiplegia & 10 & 23,26 \\
Spastik diplegia & 13 & 30,23 \\
Spastik tetraplegia & 9 & 20,93 \\
CP Diskinetik & 2 & 4,65 \\
CP Ataksik & & \\
Tingkat GMFCS & 7 & 16,28 \\
Tingkat I & 14 & 32,56 \\
Tingkat II & 4 & 9,30 \\
Tingkat III & 18 & 41,86 \\
Tingkat IV & 0 & 0 \\
Tingkat V & & \\
\hline
\end{tabular}

Tabel 2 menggambarkan klasifikasi CP berdasarkan tipe CP dan tingkat GMFCS. Berdasarkan tipenya, sebagian besar anak yaitu $32(74,42 \%)$ mengalami CP spastik dengan tipe spastik tetraplegia sebanyak 13 $(30,23 \%)$. Sedangkan berdasarkan tingkat GMFCS, sebanyak $18(41,86 \%)$ anak ditemukan pada tingkat IV.

Tabel 3. Komorbiditas CP

\begin{tabular}{lcc}
\hline \multicolumn{1}{c}{ Variabel } & Jumlah (n) & Persentase (\%) \\
\hline Gangguan berbahasa & 30 & 69,77 \\
Gangguan bahasa ekspresif & 27 & 62,79 \\
Gangguan bahasa reseptif & 1 & 2,33 \\
Gangguan bahasa ekspresif & 2 & 4,65 \\
dan reseptif & & \\
Epilepsi & 24 & 55,81 \\
Gangguan tidur & 10 & 23,26 \\
Gangguan makan & 28 & 65,12 \\
Gangguan pendengaran & 8 & 18,60 \\
Gangguan penglihatan & 22 & 51,16 \\
Retardasi mental & 39 & 90,70 \\
Gangguan BAB \& BAK & 24 & 55,81 \\
\hline
\end{tabular}

Tabel 3 menggambarkan komorbiditas pada penyandang CP. Komorbiditas yang paling banyak ditemukan adalah retardasi mental yaitu sebanyak 39 (90,70\%) anak.

Tabel 4. Gambaran banyaknya komorbiditas berdasarkan tipe CP

\begin{tabular}{lcc}
\hline \multicolumn{1}{c}{ Variabel } & Jumlah (n) & Persentase (\%) \\
\hline Spastik hemiplegia & 0 & 0 \\
Satu komorbiditas & 1 & 2,33 \\
Dua komorbiditas & 2 & 4,65 \\
Tiga komorbiditas & 6 & 13,95 \\
Lebih dari tiga komorbiditas & & \\
Spastik diplegia & 0 & 0 \\
Satu komorbiditas & 2 & 4,65 \\
Dua komorbiditas & 1 & 2,33 \\
Tiga komorbiditas & 7 & 16,28 \\
Lebih dari tiga komorbiditas & & \\
Spastik tetraplegia & 0 & 0 \\
Satu komorbiditas & 1 & 2,33 \\
Dua komorbiditas & 2 & 4,65 \\
Tiga komorbiditas & 10 & 23,26 \\
Lebih dari tiga komorbiditas & &
\end{tabular}

Tabel 5. Gambaran banyaknya komorbiditas berdasarkan tipe CP

\begin{tabular}{lcc}
\hline \multicolumn{1}{c}{ Variabel } & Jumlah (n) & Persentase (\%) \\
\hline Diskinetik & 0 & 0 \\
Satu komorbiditas & 1 & 2,33 \\
Dua komorbiditas & 1 & 2,33 \\
Tiga komorbiditas & 7 & 16,28 \\
Lebih dari tiga komorbiditas & & \\
Ataksik & 0 & 0 \\
Satu komorbiditas & 1 & 2,33 \\
Dua komorbiditas & 1 & 2,33 \\
Tiga komorbiditas & 0 & 0 \\
Lebih dari tiga komorbiditas & 0 \\
\hline
\end{tabular}

Tabel 4 menggambarkan distribusi komorbiditas berdasarkan tipe CP. Data yang didapatkan menunjukkan bahwa komorbiditas lebih dari tiga ditemukan paling banyak pada tipe spastik tetraplegia $(23,26 \%)$.

Tabel 6. Gambaran banyaknya komorbiditasi berdasarkan tingkat GMFCS

\begin{tabular}{lcc}
\hline \multicolumn{1}{c}{ Variabel } & Jumlah (n) & Persentase (\%) \\
\hline Tingkat I & 0 & 0 \\
Satu komorbiditas & 2 & 4,65 \\
Dua komorbiditas & 1 & 2,33 \\
Tiga komorbiditas & 4 & 9,30 \\
Lebih dari tiga komorbiditas & & \\
Tingkat II & 0 & 0 \\
Satu komorbiditas & 1 & 2,33 \\
Dua komorbiditas & 5 & 11,63 \\
Tiga komorbiditas & 8 & 18,60 \\
Lebih dari tiga komorbiditas & & \\
Tingkat III & 0 & 0 \\
Satu komorbiditas & 1 & 2,33 \\
Dua komorbiditas & 0 & 0,98 \\
Tiga komorbiditas & 3 & \\
Lebih dari tiga komorbiditas & & \\
\hline
\end{tabular}

Tabel 7. Gambaran banyaknya komorbiditasi berdasarkan tingkat GMFCS

\begin{tabular}{lcc}
\hline \multicolumn{1}{c}{ Variabel } & Jumlah (n) & Persentase (\%) \\
\hline Tingkat IV & 0 & 0 \\
Satu komorbiditas & 2 & 4,65 \\
Dua komorbiditas & 3 & 6,98 \\
Tiga komorbiditas & 13 & 30,23 \\
Lebih dari tiga komorbiditas & & \\
\hline
\end{tabular}

Tabel 5 menggambarkan distribusi komorbiditas berdasarkan tingkat GMFCS. Dari data yang didapatkan dapat dilihat bahwa komorbiditas lebih dari tiga ditemukan paling banyak di tingkat IV (30,23\%).

CP dapat terjadi pada laki-laki maupun perempuan. Namun, sebagian penelitian melaporkan bahwa kejadian CP pada laki-laki sedikit lebih tinggi dibandingkan 
dengan perempuan (Romeo, 2016). Dari hasil penelitian ini didapatkan dari 43 anak CP, sebanyak 22 anak adalah laki-laki dan 21 anak adalah perempuan. Penelitian serupa pernah dilakukan di Bandung pada tahun 20112012, hasilnya menunjukkan dari 31 anak CP, terdapat 16 anak laki-laki dan 15 anak perempuan (Puspitasari, 2014). SCPE melaporkan insidensi CP lebih tinggi pada laki-laki dengan perbandingan laki-laki : perempuan yaitu 1,33 : 1. Teori Johnston dan Hagberg menyatakan CP lebih sering terjadi pada laki-laki dibanding perempuan karena adanya hormon seperti estrogen yang memberikan proteksi terhadap kerusakan hipoksik-iskemik pada perempuan (Johnston \& Hagberg, 2007). Pada penelitian ini perbandingan antara laki-laki dan perempuan hampir sama. Hal tersebut tidak dapat menggambarkan teori yang ada karena penelitian tidak mencakup seluruh populasi CP.

Berdasarkan distribusi usia, sebagian besar anak CP yang bersekolah di sekolah-sekolah ini ada pada rentang usia 13-18 tahun yaitu $19(44,19 \%)$ anak. Selain itu terdapat 9 (20,93\%) anak yang berada di usia lebih dari 18 tahun. Fidan dan Baysal melakukan penelitian serupa terhadap anak-anak yang terdaftar di klinik rawat jalan dan rawat inap di Turki dan melaporkan kasus terbanyak berada di rentang usia 2-5 tahun (Fidan \& Baysal, 2014). Penelitian lain yang dilakukan di Instalasi Rehabilitasi Medik RSUP Prof. Dr. R. D Kandou Manado menunjukkan bahwa kasus terbanyak terjadi pada usia 1-5 tahun (Sitorus, 2015). Perbedaan distribusi usia ini bisa terjadi karena adanya perbedaan latar belakang tempat penelitian. Penelitian ini dilakukan di SLB, subjek penelitian berada pada usia sekolah dan gejala-gejala pada anak CP disini sebagian besar sudah dapat terkendali dengan baik. Adanya gangguan kognisi yang sering terjadi pada anak CP dapat menjadi salah satu penyebab terlambatnya usia sekolah anak CP dibandingkan dengan anak-anak seusia mereka pada umumnya, sehingga masih ditemukan anakanak dengan usia diatas 18 tahun yang masih bersekolah di SLB.

Pada hasil penelitian di tabel 2 didapatkan bahwa sebagian besar anak yaitu 32 (74,42\%) mengalami CP spastik dengan $13(30,23 \%)$ anak termasuk dalam tipe spastik tetraplegia, $10(23,26 \%)$ spastik diplegia, 9 $(20,93 \%)$ spastik hemiplegia, 9 (20,93\%) diskinetik, dan ataksik sebanyak $2(4,65 \%)$. Penelitian berbasis populasi yang dilakukan oleh Shevel dkk juga menunjukkan bahwa $86 \%$ anak CP memiliki tipe spastik dengan tetraplegia sebanyak 35\% (Shevel, 2009). Demikian juga dengan penelitian Gabis dkk yang menyebutkan dalam penelitiannya terdapat $62,4 \%$ kasus tetraplegia, $15 \%$ diplegia, 12\% hemiplegia, dan 11\% diskinetik (Gabis, 2015). Hendriana dkk melaporkan dari empat tipe CP yang diteliti di YPAC Cabang Semarang pada tahun 2006, tipe spastik merupakan tipe yang paling banyak ditemukan yaitu sebanyak $82 \%$, diikuti tipe campuran $12 \%$, tipe ataksik $4 \%$, dan tipe diskinetik $2 \%$ (Selina, 2012). CP biasanya diklasifikasikan menjadi beberapa tipe berdasarkan topografi sebagai hasil dari berbagai macam kerusakan yang terjadi pada berbagai area dalam sistem saraf yang masih berkembang (Graham, 2016). Kerentanan struktur otak yang berbeda dan jenis kerusakan yang terkait sangat dipengaruhi oleh usia kehamilan saat perkembangan otak terganggu (Marret, 2013). Cleves dkk menyatakan bahwa spastik tetraplegia lebih sering terjadi pada bayi baru lahir dengan usia kehamilan cukup bulan dengan cedera hipoksik-iskemik (Cleves, 2011).

Berdasarkan tingkat GMFCS, terdapat 18 (41,86\%) anak pada tingkat IV, 14 (32,56\%) anak pada tingkat II, 7 $(16,28 \%)$ anak pada tingkat I, dan $4(9,30 \%)$ anak pada tingkat III. Hal ini berbeda dengan beberapa penelitian lain. Majnemer dkk melaporkan dari 95 anak, 47\% termasuk ke dalam tingkat I, 18\% ada pada tingkat II-III, dan 34\% ada pada tingkat IV-V (Majnemer, 2010). Sementara itu Shevel dkk melaporkan tingkat GMFCS yang paling banyak ditemukan dalam penelitiannya adalah GMFCS tingkat 1 yaitu 44\% (Shevel, 2009). GMFCS menggambarkan karakteristik fungsional morotik kasar dalam lima tingkat, dari I sampai $\mathrm{V}$, dengan tingkat I merupakan tingkat yang paling ringan. Semakin tinggi tingkat GMFCS semakin berat pula keterbatasan fungsional yang dialami oleh anak tersebut (Rethlefson, 2010). Hal tersebut mungkin dapat menjelaskan mengapa lebih banyak anak pada GMFCS tingkat IV yang bersekolah di SLB.

Hasil penelitian ini menunjukkan sebanyak 39 $(90,70 \%)$ anak mengalami retardasi mental, 30 (69,77\%) anak memiliki gangguan berbahasa, $28 \quad(65,12 \%)$ anak memiliki gangguan makan, 24 (55,81\%) anak memiliki epilepsi, 24 (55,81\%) anak memiliki gangguan BAB\&BAK, 22 (51,16\%) anak memiliki gangguan penglihatan, $10(23,26 \%)$ anak memiliki gangguan tidur, dan $8(18,60 \%)$ anak memiliki gangguan pendengaran. Penelitian mengenai komorbiditas pada penyandang $\mathrm{CP}$ juga dilakukan oleh Ioana Minciu di Romania pada tahun 2010 dan hasilnya menunjukkan sebanyak $80,2 \%$ anak mengalami retardasi mental, 49,9\% mengalami epilepsi, 49,6\% mengalami gangguan penglihatan, $8,7 \%$ mengalami gangguan berbahasa, 2,6\% mengalami gang-guan pendengaran, dan $10 \%$ mengalami gangguan menelan (Minciu, 2012). Penelitian meta-analisis melaporkan pada semua anak-anak (lahir cukup bulan dan prematur) dengan CP 75\% memiliki komorbiditas nyeri, 49\% memiliki gangguan kognisi, 16\% memiliki keterbatasan gerak, $23 \%$ gangguan berbahasa, 28\% mengalami hip displacement, $26 \%$ memiliki gangguan perilaku, $24 \%$ memiliki epilepsi, $24 \%$ memiliki gangguan tidur, $23 \%$ mengalami masalah dengan kontinuitas, $22 \%$ drooling, $11 \%$ mengalami gangguan penglihatan, $6 \%$ gangguan makan, dan $4 \%$ mengalami gangguan pendengaran (Spittle, 2014).

Menurut literatur, sebanyak 30\%-50\% anak CP diperkirakan memiliki retardasi mental. Penurunan kemampuan kognitif ini lebih sering terlihat pada tipe spastik tetraplegia (Pruitt, 2009). Tingginya angka retardasi mental pada anak $\mathrm{CP}$ sesuai dengan literatur 
yang menyebutkan, selain gangguan motorik, satu dari dua orang anak CP memiliki gangguan intelektual (Novak, 2012). Hasil penelitian Mejnemer dkk juga mengindikasikan bahwa penyandang CP dengan tingkat GMFCS IV-V memiliki kemampuan kognitif yang lebih rendah (Mejnemer, 2010). Anak CP tanpa retardasi mental mungkin masih dapat disekolahkan di sekolah umum karena tidak adanya gangguan kognisi yang dapat memperngaruhi proses belajar. Hal ini menjelaskan mengapa retardasi mental merupakan komorbiditas yang paling banyak ditemukan pada anak penyandang $\mathrm{CP}$ di SLB.

Gangguan berbahasa ditemukan pada 69,77\% anak CP dalam penelitian ini. Hasil ini tidak jauh berbeda dengan hasil penelitan SCPE yang menunjukkan $71 \%$ anak CP memiliki gangguan berbahasa (Gabis, 2015). Gangguan berbahasa merupakan komorbiditas yang sering terjadi pada anak CP (Pennington, 2012). Gangguan ini merupakan hasil interaksi yang kompleks antara gangguan motorik, menelan, drooling, gangguan intelektual, gangguan penglihatan dan pendengaran yang selanjutnya dapat membatasi kemampuan anak (Parkes, 2010).

Gangguan makan juga ditemukan pada 65,12\% anak CP. Berdasarkan literatur, gangguan makan juga merupakan salah satu komorbiditas yang erat kaitannya dengan CP. Gangguan makan yang terjadi biasanya dapat menyebabkan masalah nutrisi dan pertumbuhan. Gangguan ini biasanya berkaitan dengan disebabkan adanya gangguan pada saraf kranial yang mempersarafi berbagai otot yang berfungsi dalam pembentukan bolus dan proses menelan makanan (Pruitt, 2009). Gangguan pada perkembangan dan koordinasi otot wajah, terutama otot perioral menyebabkan memburuknya kemampuan mengisap, menelan, dan artikulasi (Fidan \& Baysal, 2014).

Dalampenelitian ini epilepsiditemukan pada $55,81 \%$ anak CP. Epilepsi sering terjadi pada individu dengan CP. Prevalensi yang dilaporkan pada literatur sangat bervariasi tergantung pada tipe $\mathrm{CP}$, jenis kejang, dan ada atau tidaknya retardasi mental. Secara keseluruhan, prevalensi kejang pada anak-anak dan orang dewasa dengan CP telah dilaporkan antara 15\% dan 55\% (Pruitt, 2009). Berbagai penelitian memperlihatkan bahwa gangguan neurologis seperti CP akan meningkatkan risiko terjadinya epilepsi, dan mekanisme terjadinya epilepsi pada CP sama dengan mekanisme pada populasi umum (Sankar, 2006).

Gangguan BAB\&BAK juga ditemukan pada 55,81\% anak CP. Gangguan pencernaan dan nutrisi merupakan masalah yang sering ditemukan pada anak CP. Hal ini biasanya terjadi akibat kerusakan pada sistem saraf enterik yang mengakibatkan gangguan motilitas. Anak CP juga beresiko memiliki masalah yang berkaitan dengan saluran kemih. Spastisitas dan hiperrefleksia dari otot skeletal dapat diikuti dengan spastisitas pada otot detrusor yang menyebabkan kapasitas kandung kemih menurun (Pruitt, 2009).
Komorbiditas lain juga ditemukan dalam penelitian ini, diantaranya gangguan penglihatan $(51,16 \%)$, gangguan tidur $(23,26 \%)$, dan gangguan pendengaran $(18,60 \%)$. Anak CP memiliki abnormalitas visual yang lebih banyak dibandingkan anak normal. Penelitian menunjukkan abnormalitas visual pada anak CP bervariasi mulai dari 10\%-100\% (Pruitt, 2009). Selain itu, gangguan tidur juga banyak ditemukan pada anak CP. Gangguan tidur yang terjadi pada anak CP dapat disebabkan oleh beberapa faktor. Kejang otot, nyeri, penurunan kemampuan untuk mengubah posisi pada malam hari, epilepsi, dan gastroesophageal reflux disease (GERD) adalah beberapa dari banyak masalah terkait yang dapat menyebabkan gangguan tidur pada anak CP. Komorbiditas lain yang juga ditemukan pada anak CP adalah gangguan pendengaran. Gangguan pendengaran terjadi pada sekitar 30\%-40\% anak CP(Pruitt, 2009). Hasil penelitian Venkateswaran dkk menyebutkan bahwa gangguan pendengaran ditemukan pada 22\% anak CP (Venkateswaran, 2008). Gangguan pendengaran merupakan komplikasi paling umum yang dapat memperburuk gangguan berbahasa (Gabis, 2015).

Tipe CP spastik tetraplegia memiliki komorbiditas lebih dari tiga paling banyak diantara tipe lainnya yaitu sebanyak $10(23,26 \%)$ pada spastik tetraplegia. Banyaknya komorbiditas yang ada pada anak CP menunjukkan tingkat keparahan dan prognosis dari anak tersebut (Minciu, 2012). Berdasarkan topografinya, spastik tetraplegia memiliki komorbiditas yang lebih banyak dibandingkan dengan yang lainnya. Hal ini juga sesuai dengan penelitian Wong dkk yang melaporkan bahwa anak dengan tetraplegia memiliki keterbatasan fungsional yang lebih berat dibandingkan dengan anak dengan diplegia atau hemiplegia (Wong, 2004). Sianturi dkk juga melaporkan bahwa spastik tetraplegia adalah tipe spastik yang memiliki disabilitas lebih parah (Sianturi, 2002). Penelitian lain juga menyebutkan bahwa anak CP spastik tetrplegia memiliki frekuensi komorbiditas yang tinggi. Adanya komorbiditas ini dapat menambah beban penyakit dan mempengaruhi kualitas hidup anak maupun keluarganya (Venkateswaran, 2008).

Pada penelitian ini juga didapatkan bahwa pada tingkat GMFCS I anak dengan komorbiditas lebih dari tiga ada $4(9,30 \%)$ anak, pada tingkat II ada $8(18,60 \%)$ anak, pada tingkat III ada $3(6,98 \%)$ anak, dan pada tingkat IV ada $13(30,23 \%)$ anak. Komorbiditas lebih dari tiga paling banyak ditemukan pada GMFCS tingkat IV. Penelitian dari University of Medicine and Pharmacy, Romania menyatakan bahwa tidak adanya komorbiditas sangat berkaitan secara signifikan dari sudut pandang statistik dengan GMFCS I. Sedangkan komorbiditas yang lebih banyak erat kaitannya dengan tingkat GMFCS yang lebih tinggi (Minciu, 2012). Majnemer dkk juga menyatakan bahwa keterbatasan fungsional lebih mungkin terjadi pada anak dengan tetraplegia dan anak yang berada pada tingkat IV-V GMFCS (Majnemer, 2010). Hal ini dapat dikaitkan dengan tingkat keparahan dari kerusakan atau lesi serebral yang terjadi pada anak CP (Gabis, 2015). 
Terdapat beberapa keterbatasan pada penelitian ini yaitu adanya recall bias pada saat anamnesis sehingga beberapa pertanyaan tidak dapat terjawab secara pasti. Selain itu, penelitian ini melibatkan subjek yang relatif sedikit dan hanya melibatkan beberapa SLB di Bandung. Penelitian lebih lanjut dengan jumlah subjek yang lebih banyak dan cakupan daerah yang lebih luas diperlukan untuk memberikan hasil yang lebih akurat.

\section{SIMPULAN}

Komorbiditas yang paling banyak ditemukan pada anak penyandang CP di SLB adalah retardasi mental. Jumlah komorbiditas yang dialami terlihat lebih banyak pada anak dengan tipe spastik tetraplegia. Sedangkan dilihat dari tingkat GMFCS, komorbiditas lebih banyak ditemukan pada tingkat GMFCS IV.

\section{DAFTAR PUSTAKA}

Centers for Disease Control and Prevention. (2016). Data and Statistics for Cerebral Palsy.

Cleves, Catalina., Lee, Jung Woo., Kabongo, L. Martin. (2011). Cerebral palsy. Medicina, 67(6 Pt 1), 586-592.

Das, N., Bezboruah, G., \& Das, I. (2016). Study on the Clinical Profile of Patients with Cerebral Palsy. International Organization of Scientific Research Journal of Dental and Medical Sciences, 15(07), 54-58.

Departemen Kesehatan Jawa Barat. (2012). Profil Kesehatan Provinsi Jawa Barat Tahun 2012. Profil Kesehatan Provinsi Jawa Barat Tahun 2012, 34 36.

Fidan, F., \& Baysal, O. (2014). Epidemiologic Characteristics of Patients with Cerebral Palsy. Journal of Therapy and Rehabilitation, 2(August), 126-132.

Gabis, L. V., Tsubary, N. M., Leon, O., Ashkenasi, A., $\&$ Shefer, S. (2015). Assessment of Abilities and Comorbidities in Children With Cerebral Palsy. Journal of Child Neurology, 30(12), 1640-1645.

Graham, H. K., Rosenbaum, P., Paneth, N., Dan, B., Lin, J. P., Damiano, Di. L., Lieber, R. L. (2016). Cerebral palsy. Nature Reviews Disease Primers, 2.

Johnston, M. V., \& Hagberg, H. (2007). Sex and the pathogenesis of cerebral palsy. Developmental Medicine and Child Neurology, 49(1), 74-78.

Kumari, a, \& Yadav, S. (2012). Cerebral Palsy: a Mini Review. Internation Journal of Theurapetic Applications, 3, 15-24.
Majnemer, A., Shevell, M., Hall, N., Poulin, C., \& Law, M. (2010). Developmental and Functional Abilities in Children With Cerebral Palsy as Related to Pattern and Level of Motor Function. Journal of Child Neurology, 25(10), 1236-1241.

Marret, S., Vanhulle, C., \& Laquerriere, A. (2013). Pathophysiology of cerebral palsy. Handbook of Clinical Neurology, 111, 169-176.

McInerny, T. K., Adam, H. M., DeWitt, T. G., \& Campbell, D. E. (2016). American Academy of Pediatrics Textbook of Pediatric Care (2nd Edition). American Academy of Pediatrics.

Minciu, I. (2012). Clinical correlations in cerebral palsy. Mcedica, 7(4), 319-324.

National Institute of Neurological Disorders and Stroke (NINDS). (2013). Cerebral Palsy: Hope Through Research. National Institutes of Health, 13-159.

Novak, I., Hines, M., Goldsmith, S., Barclay, R., (2012). Clinical prognostic messages from a systematic review on cerebral palsy. Pediatrics 130, e1285e1312

Pakula, A. T., \& Braun, K. V. N. (2009). Cerebral Palsy: Classification and Epidemiology. Physical Medicine and Rehabilitation Clinics of North America, 20(3), 425-452.

Palisano, R., Rodenbaum, P., Bartlett, D., Livingston, M. (2007). Gross Motor Function Classification System Expanded and Revised. CanChild Center for Childhood Disability Research, McMaster University.

Parkes, J., Hill, N., Platt, M. J., \& Donnelly, C. (2010). Oromotor dysfunction and communication impairments in children with cerebral palsy: A register study. Developmental Medicine and Child Neurology, 52(12), 1113-1119.

Pennington, L. (2012). Speech and communication in cerebral palsy. Eastern Journal of Medicine, 17(4), 171-177.

Pruitt, D. W., \& Tsai, T. (2009). Common Medical Comorbidities Associated with Cerebral Palsy. Physical Medicine and Rehabilitation Clinics of North America, 20(3), 453-467.

Puspitasari, M., Rusmil, K., \& Gurnida, D. (2014). The Relationship Between Gross Motor Function and Quality of Life Among Children with Cerebral Palsy. Disability, CBR \& Inclusive Development Journal, 24(4), 57-68.

Rethlefsen SA, Ryan DD, Kay RM. (2010). Classification systems in cerebral palsy. Orthopedic Clinics of North America, 41(4), 457-467. 
Romeo, D. M., Sini, F., Brogna, C., Albamonte, E., Ricci, D., \& Mercuri, E. (2016). Sex differences in cerebral palsy on neuromotor outcome: a critical review. Developmental Medicine and Child Neurology, 58(8), 809-813.

Sankar R, Koh S, Wu J, Menkes JH. (2006) Paroxysmal disorders. Dalam: Menkes JH, Sarnat HB, Maria BL, penyunting. Child Neurology. Edisi ke-7. Lippincott Williams \& Wilkins: Philadelphia;. h. 858-943.

Selina, Hendriana., Priambodo, Winres., Sakundarno,M. (2012). Gangguan Tidur pada Anak Palsi Serebral. Medica Hositalia, 1(1), 16-19.

Shevell, M. I., Dagenais, L., \& Hall, N. (2009). The relationship of cerebral palsy subtype and functional motor impairment: A populationbased study. Developmental Medicine and Child Neurology, 51(11), 872-877.

Sitorus, F. S. A. B., Mogi, T. I., \& Gessal, J. (2016). Prevalensi Anak Cerebral Palsy Di Instalasi Rehabilitasi Medik Rsup Prof. Dr. R. D. Kandou Manado. Jurnal Kedokteran Klinik, 1(1), 14-19.

Spittle AJ, Orton J.(2014) Cerebral palsy and developmental coordination disorder in children born preterm. Seminars in Fetal \& Neonatal Medicine. Elsevier, 19(2):84-9.
Stavsky, M., Mor, O., Mastrolia, S. A., Greenbaum, S., Than, N. G., \& Erez, O. (2017). Cerebral PalsyTrends in Epidemiology and Recent Development in Prenatal Mechanisms of Disease, Treatment, and Prevention. Frontiers in Pediatrics, 5, 21.

Tessier, D. W., Hefner, J. L., \& Newmeyer, A. (2014). Factors Related to Psychosocial Quality of Life for Children with Cerebral Palsy. International Journal of Pediatrics, 2014, 1-6.

Venkateswaran, S., \& Shevell, M. I. (2008). Comorbidities and clinical determinants of outcome in children with spastic quadriplegic cerebral palsy. Developmental Medicine and Child Neurology, 50(3), 216-222.

WHO. (2013). Birth Defects In South-east Asia A Public Health Challenge. World Health Organization: Regional Office for South-East-Asia, SEACAH-13, 63-70.

Wong V, Chung B, Hui S, et al. (2004). Cerebral palsy: correlation of risk factors and functional performance using the functional independence measure for children. Journal of Child Neurology, 19:87-89. 